\title{
Perception of the health of children living and working on the streets of Sunnyside Part 1: Literature review and methodology
}

\author{
L Prinsloo, M Cur, Department of Nursing Science, University of Pretoria \\ MS Richter, D Cur, Faculty of Nursing, University of Alberta* \\ * (Note during course of the study: Department of Nursing Science, University of Pretoria)
}

\section{Abstract}

The phenomenon of street children is generating increasing concern in South Africa. The number of street children has grown because of the current economic hardship in South Africa, increasing levels of violence and widespread family and community disruption.

In terms of health, it is clear that street children may be vulnerable to a range of severe risks.

The street child's view of health may differ considerably from that of the researcher. Discrepancies exist between the perceptions of the street children, and those of community health workers. This can have serious consequences when planning health promotion strategies (Jenkins \& Emmet 1997: 427).

The purpose of the study was to describe the perceptions of street children concerning their own health. A qualitative descriptive design was followed in this study. Focus groups were used to obtain data.

The findings of this research revealed five categories:

- Influences the environment has on street children's wellness

- $\quad$ Paths of homelessness of street children of Sunnyside that play a leading role in their wellness

- Wellness seeking behaviors of the street children of Sunnyside and the access to care they make use of

- $\quad$ Sources of advice and wellness education the street children of Sunnyside make use of

- Illnesses perceived by the street children of Sunnyside

\section{Introduction}

This article concentrates on the perceptions of health of children living and working on the streets of Sunnyside, Pretoria. Part one of the article will consist of the introduction and literature review and part 2 , the methodology, interpretation and recommendations.

\section{Literature review}

The phenomenon of street children is generating increasing concern in South Africa, much of this being voiced through the media. Public reaction, whether positive or negative, is often insufficiently informed and emotive in nature. It is important to clarify the nature of the problem, particularly its health implications, in more objective terms (Donald \& Swart-Kruger 1994: 169).

\section{Home street home}

Extensive literature exists on the phenomenon of street children. This literature is full of contradictions, anything from starry-eyed social romanticism to ideological oppor- tunism (Novartis Foundation 2000). Depending on the author, the street child is portrayed in every imaginable hue. One interpretation of the situation glorifies the street child as personifying a counterculture opposing the prevailing social order. In this social order the 'victim' is the street child.

Life on the streets becomes 'street culture', and its values are defined by a code of 'street ethics'. Another interpretation indulges in presenting the street child as 'charming' and 'pitiable' - but only as long as he or she is still small and 'cute'. This viewpoint changes abruptly when the child reaches puberty: the child is then described as a "delinquent, lazy, homosexual, aggressive nuisance, addicted to drugs", and therefore one that "belongs in an institution" (Novartis Foundation 2000). While dire need is indeed one of the critical factors, a childhood on the streets is the result of causes as diverse as the individual characters of children and youths themselves.

Another stereotype arises from naming all children who are out on the streets 'street children'. Most of them only appear to be left to their own fate. The street is merely their 
workplace, or for lack of well-run, affordable preschool centers and youth centers, their daytime abode. They spend all their time on the streets while their parents (often just a single mother), are at work. For this reason they are called children on the street, as opposed to the relatively small number of 'genuine' street children. The street children have little or no family ties at all, and live on the streets day and night. Given all these differences, no single strategy exists for social reintegration, or for preventing children from ending up on the streets. But the distinction between 'children on the streets' and 'children of the streets' should not obscure the fact that the step towards becoming a 'genuine' street child is very small.

The largest category of street children consists of children living in absolute poverty. These children grow up in an extremely underprivileged social environment. They lack the most elementary means to meet their basic needs, and usually receive little or no parental care. This is mostly because their mothers (who are often single parents), are forced to seek some means of subsistence. In the absence of day-care facilities, the children, even toddlers, are left on their own. This exposes them to a high risk of starting an early 'career' on the streets.

These children are forced to fend for themselves from the earliest possible age, and they may even have to contribute to the family income. They become "children on the street'. They work as shoeshine boys, sell sweets and newspapers, clean car windshields, and act as car watchers. To improve their meager daily intake, they may also beg or steal. Tragically, child prostitution and drug dealing are prevalent financial attractions too. A lack of money for the taxi-fare home frequently compels these children to spend nights on the street. They are often unwelcome at home if they do not bring enough money. It is, therefore, not easy to differentiate between them, and the 'genuine' street children.

Most 'genuine' street children, or 'children of the street', ran away from home. Others are either orphans or children who been turned out or abandoned by their parents. The street is not just their workplace, it is their home. At this stage, when the street is their home, the rupture between the child, and the adult society, is complete. These children live in a complete legal vacuum, and are therefore acutely exposed to repression and exploitation - often by police officers (Novartis Foundation 2000). The street children tolerate a life of prostitution, stealing for the officers, or giving them part of their income or booty. They can be abused or even killed, at any time.

\section{Incidence}

In estimating the number of street children, a problem exists in the formulation of an operational definition. It is a common misperception that all children, found working or begging on the streets are necessarily 'street children'. As found in Brazil, a distinction needs to be drawn between children actually living on the streets, and those working on the streets (Ennew 1996: 203). The latter situation is common throughout the world. Children are widely involved in income generating activities to help themselves, or their families. Richter (1988: 11) defines children of the street as those who "have abandoned (or have been abandoned by) their families, schools and immediate communities, before they are sixteen years of age, and have drifted into nomadic street life."

A pragmatic solution to the problem has been to ask the children themselves. Street children commonly have terms they use to describe themselves. In Cape Town, they call themselves 'strollers' (Scharf, Powell \& Thomas 1986: 262). In Johannesburg, the children refer to themselves as 'malalapipe' or 'malunde' (Swart 1990: 5). Once the local term used by the children has been identified, those who do not know it, or who strongly refuse to be labeled with it, are unlikely to be 'children of' the street' (Swart-Kruger 1994: 169). In Sunnyside, they are called 'mala pipe' (pipe sleepers).

It is now widely accepted that there are generally far fewer 'children of the street' than there are 'children on the street' (Espinola, Glauser, Oritz \& de Carrizosa 1987: 6). Prior to 1990 , more than one million children were estimated to be 'on the street' in South Africa, including those working on farms. At the same time, it was estimated that there were in the region of 10,000 children 'of the street' (Swart 1990: 12). The effects of current economic factors in South Africa, the increasing levels of violence, and AIDS orphans, in both townships and rural areas, are not known. It is likely, however, that the number of street children has grown, as a result of increased economic hardships and widespread family and community disruption. Thus, despite a lack of precise information, indications are that the number of 'genuine' street children in South Africa is substantial and growing.

\section{Street children: their aetiology}

The phenomenon of street children worldwide is generally directly linked to rapid industrialization, urbanization, and the concomitant breakdown of extended family ties. Childhood security, in the traditional sense of being contained within a family system, is being shaken by divorce, desertion, suicide, alcoholism and child abuse, all of which are "increasing inexorably" (Swart 1990: 5). These factors may be accentuated where poverty and destitution are endemic.

Accidents and illness may leave children unprotected, and illegitimacy means that many children start life in single parent families, with all its associated stresses. Harsh or neglectful treatment of children frequently derives from parental depression, anger, anxiety and frustration. A cramped physical environment exacerbates health problems, and frustrations are frequently vented on the children (Swart 1988: 34).

The street children of Sunnyside fall into two main categories: 'push-outs' or 'throw-aways', and 'runaways'. 'Push- 
outs' or 'throw-aways' are children who have been abandoned or orphaned. Relatives or the local community do not wish to take responsibility for them. They are also children who have intact homes of origin, but who have been rejected and forced to leave, frequently by stepparents. 'Runaways' seek an escape from poverty, brutality, neglect, or responsibilities beyond their capacity. Their families appear glad to be rid of them. Running away is therefore not necessarily a sign of delinquency or emotional disorder; it can also be a cry of pain or a sign of health seeking surfacing (Allison \& Jerrom 1984:453). Some children run away from soul-destroying boredom. These children, who are on the streets merely to seek excitement, cause their parents great anguish when they disappear (Swart 1988: 34).

The street children in Sunnyside are almost exclusively black; a few are white or colored. Blacks outnumber other populations, 5: 1, in South Africa. However, segregated institutional care facilities are disproportional, at 9: 200, in favor of non-black population groups (Swart 1988: 35). Furthermore, throughout the world, street children tend to come from the lower socio-economic classes. In South Africa, this is predominantly the black population. In 1987, the unemployment rate in Soweto was twenty-eight per cent (281\%) (Venter 1997: 12).

Unrest in the townships, especially in schools, has driven children to the streets. Young boys have found themselves not only victimized by older, more politically aware brothers, but also terrified at the thought of possible indiscriminate police round-ups of agitators. In some instances they have come to Sunnyside searching for alternative schooling, in instances where formal schooling is disorganized or uncontrolled. Street children tend to be very confused by the schooling situation.

In Sunnyside, as elsewhere in the world, street children are predominantly male. Though the reason for this has not yet been adequately researched, it appears that girls are abandoned less frequently. When the family disintegrates, relatives and neighbors are more willing to take in girls than boys, since the girls can assist with household tasks and child minding. When girls drift onto the streets in their teens, they tend to become prostitutes and find accommodation, rather than remain on the streets (Richter 1988: 11). It is difficult to estimate the number of street children, because they are nomadic. Many of them migrate to warmer climates in the winter, for example; from Sunnyside to Durban. They "are outside all official statistics, though perfectly visible from the hotel window" (Richter 1988: 14). A conservative estimate, of their numbers worldwide, is eighty million (Scharf \& Powell \& Thomas 1986: 47-48). Their number in South Africa has been estimated at close to 5,000. Increasing enquiries, from concerned persons throughout South Africa, seem to indicate that their numbers are far greater than this (Venter 1997: 18).

\section{The lifestyle of street children}

Society tends to see street children as insubstantial, be- cause they hover on the periphery of other people's lives. This is reflected in the generic Afrikaans term 'skadukinders' (children of the shadows), and in English, 'twilight children'. The children themselves are more down to earth, in labeling themselves as 'strollers' or 'pipe sleepers'.

Street children take great pride in earning their living through tasks like shoe shining, assisting shoppers with their parcels and trolleys, guiding cars into parking bays, sweeping pavements, doing odd jobs for shopkeepers, and selling newspapers, flowers and cellular phone accessories, on street comers. A number of them are prepared to be 'chip-chop' boys, that is, to sell sexual favours to men and women, but few state that they enjoy such activities (Swart 1988: 35-36). Street children, as a whole, have a sense of dignity and self-worth that is not always perceptible beneath the grime.

That the streets are 'schools of crime', and that street children will inevitably become criminals, is more popular belief than reality. Many young men who grew up on the streets have respectable employment now (Venter 1997: 22). In apprehending and treating children as criminals, society may place them on the path to criminality. Worldwide, street children are fearful of the police. In personal interviews with the children in Sunnyside, only nine out of fifty report never having been in a police vehicle. In South Africa, street children are arrested for begging, loitering, theft, and being a nuisance. According to Williams (1996: 33), it is: "theoretically possible in this context that a child as young as seven can be arrested, held as an awaiting prisoner, charged, tried, convicted and sentenced, without a lawyer, or at rental assistance."

While it is not official police practice to brutalize children, the children constantly report instances of maltreatment, by members of the police.

By being on the streets, the children distance themselves physically from the problems in the home environment. But street conditions are far from idyllic, and, in order to escape the unpleasantness of street life, about ninety five per cent (95\%) of the children become glue addicts (Swart 1988: 36).

'Smoking glue', as the children call it, is the inhalation of noxious fumes through the mouth. This is most easily done by decanting shoemaker's glue into soft plastic bottles. The toluene in the substance, to which the children are addicted, is destructive, affecting first the respiratory and then the nervous system. The nasal membranes and trachea break down first, causing sore throats and runny noses. This is unattractive to the hygiene conscious citizens, from whom the child seeks sustenance. 'Smoking glue' causes vivid, frightening hallucinations and impairs motor co-ordination. It is a disorienting and numbing experience. Vision may become permanently impaired. Constant glue addiction can result in brain damage and total bone marrow deterioration (Street children and Inhalants 2000).

Street children tend to live in groups, both for companionship and safety. They are not gangs in the sense of having 


\begin{tabular}{|c|c|c|}
\hline \multicolumn{3}{|l|}{ Macro level } \\
\hline \multicolumn{3}{|l|}{ Education system } \\
\hline Poverty & \multicolumn{2}{|l|}{ Industrialization } \\
\hline Poor health and nutrition & \multicolumn{2}{|l|}{ Inequity } \\
\hline Overpopulation & \multicolumn{2}{|c|}{ Influx control system } \\
\hline Township unrest & \multicolumn{2}{|l|}{ Urbanization } \\
\hline Political violence & \multicolumn{2}{|c|}{ Migration to urban areas } \\
\hline Unemployment & \multicolumn{2}{|c|}{ Migrant labor system } \\
\hline \multicolumn{3}{|l|}{ Meso level } \\
\hline Inadequate housing & Breakdown of family ties & Single parenthood \\
\hline Public social policies & Remarriage rejection & Illegitimacy \\
\hline Teenage pregnancies & Large families & Child abuse or neglect \\
\hline Death, desertion, divorce & \multicolumn{2}{|c|}{ Westernization, traditional cultural values decline } \\
\hline \multicolumn{3}{|l|}{ Micro level (Individual) } \\
\hline \multirow{2}{*}{\multicolumn{2}{|c|}{$\begin{array}{l}\text { Child: School failure and dropout } \quad \text { Parents: } \\
\text { Boredom }\end{array}$}} & Illness, alcohol abuse \\
\hline & & Psychopathology \\
\hline \multicolumn{2}{|c|}{ Psychological and motivational } & Anger and frustration \\
\hline \multicolumn{2}{|l|}{ Personality factors } & Depression \\
\hline \multicolumn{3}{|l|}{ Characteristics } \\
\hline \multicolumn{3}{|c|}{ Family background and factors } \\
\hline \multicolumn{3}{|c|}{ Lack of skills to cope with problems } \\
\hline
\end{tabular}

antisocial gang ethics, but some of these groups may develop into, or join gangs (Cockburn 1991: 38).

Children who choose to remain on the streets, maintain that they are able to find food, clothing and shelter, but they cannot obtain the education, which they feel will enable them to upgrade their lives (Swart 1988: 38).

\section{Why become street children?}

There are certain factors that lead to a child's flight to the streets (Barret 1995: 19). Barret has certain views on these factors referring to South Africa. To describe these views, she makes use of three levels.

Looking closer at the situation in South Africa, Barret (1995: 31-40) refers to the collapse of families, as a major factor why children opt for the streets. This will be discussed under the following headings: lack of a father figure; divorce of parents; step-parents; parentless child; abandoned children; talented children; alcoholic parents; excessively strict parents; prostitute mothers; hungry children; abused children and delinquent children.

\section{Lack of a father figure}

It is possible that some boys will not hesitate to leave home, for the streets, in search of a father figure. A gang leader will often fill this gap.

\section{Divorce of parents}

Diaries of street children are full of descriptions of wife battering, physical assault and molestation (Williams 1996: 42). Disputes between parents sometimes lead to divorce and always involves the whole family. This often makes the situation at home impossible to cope with. Children very often opt for the streets, to avoid the stress at home.

\section{Stepparents}

The divorce of parents often leads to another marriage. In such a situation, a child has to cope with a stepparent. It often happens that the child stays with his father. In this situation, the stepmother can accuse the boy of all kinds of 
things, to show him that she does not want him there. On the other hand, a stepfather may feel that he should not be responsible for the child. This could also be worsened by financial constraints.

\section{Parentless child}

Following a divorce, it often happens that a child finds there is no place for him in either home. He feels unwanted with two different sets of parents.

\section{Abandoned children}

It often happens that the mother of a child born out of wedlock - often a minor - becomes a single parent because the father walks away from the situation. These mothers may abandon their children because of a lack of resources, or because they cannot cope with the situation.

Children with bad friends, who sniff glue, fight, steal, or refuse to go to school, make it impossible for parents to control them. These children face the risk of being chased away. After a divorce, or even when both parents work far away, children often live with their grandparents. If both grandparents die, these children often have nowhere to go.

\section{Talented children}

Talented children tend to become frustrated in school, or parents do not see the need for education. These children will go to the streets to earn money for education. In an assessment study conducted for Street-Wise in South Africa (Richter 1996: 33), the previous schooling of street children was measured. An alarming sixty-six per cent $(66 \%)$, of the boys, have not completed five years of schooling. In our terms they are 'uneducated'

\section{Alcoholic parents}

All the parents' money goes into alcohol and they leave little or nothing for food. They are drunk most of the time and do not care for the children.

\section{Excessively strict parents}

Children with parents, who do not understand the child's psychology, do not understand parents who give their children more freedom. For the child of excessively strict parents, it seems as if there is more freedom on the streets.

\section{Prostitute mothers}

Boys often lose respect for their mothers because of what they are doing. They are also sometimes forced to call the visiting men 'uncle'. Mothers, with guilty consciences, sometimes try to compensate by giving money or gifts.

\section{Hungry children}

Unemployment, or other circumstances, sometimes deprives children of their basic needs. The streets, and the opportunities they offer, are often seen as an outcome.

\section{Abused children}

Abused children fear the mistakes they make, for the pun- ishment they receive. When that 'big' mistake happens, they rather run away, than face the vicious consequences.

\section{Delinquent children}

These boys are often abandoned because of their actions.

\section{How street children survive in South Africa}

The researcher's involvement with SAFCOTS (The Sunnyside Alliance For Children On The Streets), resulted in the researcher enjoying the privilege of being part of the group that arranged the first 'street sleep-out' ever, to take place in South Africa. It took place on 27 April 1996. The aim of the sleep-out was to promote awareness of the difficulties street children face - especially during winter. It was a huge success and enjoyed wide media coverage. After this occasion the researcher became involved with the street children of Sunnyside.

The second sleep-out took place on 15 June 1997. Again, the media was present, and even more people (76), came to spend the night in Esselen Street. The people undertook different tours during the first half of the night; visiting the shelter for street children in Vos Street (Itumeleng); visiting the day-care facility that Street-Wise use; and visiting the police station, which most street children know very well. In the second half of the night, participating people wrapped themselves in the one blanket allowed for the night, and tried to relax on the hard and cold pavement of Esselen Street.

Apparently, sleeping, on a freezing night, on a solid, rocklike surface, is not the only hardship a street child faces. Discussion of other problems follows:

\section{Finances}

Most street children do jobs to find money or food, to survive. These include helping motorists park, washing cars, selling fruit and vegetables, begging, prostituting themselves, selling drugs, committing minor (and more serious) crimes, pushing trolleys, and collecting trolleys. They use their earnings for food, drugs, glue or benzene. If anything is left, they use it to play video games at the local café or shop (Venter 1997: 16).

\section{'Street family'}

Street children generally live in 'gangs'/groups with a gang leader - usually the oldest boy, or the one that can protect them the best. Some children feel that they want to change groups after a while on the streets. It sometimes happens that smaller children are beaten up for their money. In order not to fall victim of 'other people' (those not in their gang or the police), the children in the group have to care for each other. One of their characteristics is generosity. The groups also have a sense of solidarity with the weak and poor. 


\section{Eating habits}

The children on the streets eat when they are hungry, and when they can afford it. If they have no food or money, they sniff glue or benzene (Casa Alianza 2000). This takes away the feelings of hunger, cold or depression.

\section{Sleeping habits}

Street children tend to sleep, in their groups, in public places or street pipes. Public places are a risk, especially for the smaller boys, because of sexual abuse. Most of them only go to sleep at 23:00, when the majority of people leave their area. They awake in the mornings, just before the shops open, at about 09:00. Smaller children, who are afraid of the dark, sometimes sleep during the daytime and stay awake at night.

\section{Personal hygiene and health care}

Personal cleanliness is of utmost importance to the street child (Venter 1997: 17). They wash daily, at public taps, or at a garage. If there is a river nearby, they wash there over weekends.

Homeless children are at great risk for health, mental health and developmental disorders. Problems, like crowding into shelters, a lack of privacy, bad hygiene, and an inability to prepare and store food, often lead to respiratory illnesses, otitis, skin infections, scabies, lice, bowel disorders, dental decay and anemia. Preventative health care is a low priority for street children, faced with the need to find basic necessities. Continuity of care is difficult to achieve when children have no stable residence (Simms 1998: 488).

Although many surveys find that mental health problems are common in street children, researchers have not generally employed formal measures to make psychiatric diagnoses (Buckner \& Bassak 1997: 890). Lacking parental support, street children are vulnerable to serious health and social consequences. To survive on the streets, they become involved in alcohol and drug abuse, physical violence, crime and prostitution or 'survival sex' (the exchange of sex for food, a place to stay, money, drugs or protection). Predictably, the prevalence of sexually transmitted diseases of all types, including HIV infection, as well as unintended pregnancies (Simms 1998: 488), is very high.

Many children practice self-medication, or delay seeking medical advice, which can be very dangerous. Because of the lack of money, and their stature, children almost never go to clinics or hospitals for medical care (CAS 2000).

\section{Fears of street children}

Fezile (NICRO 1997: 3) says: "I was walking with two friends and the police started beating us up without asking questions. We had glue with us." Rajani and Kadrati (Williams 1996: 33) point out that "virtually all street children identify violence as their greatest fear and concern."

\section{Police}

A child, in Cape Town, reports (Williams 1996: 42): "Sometimes they let us fly 'airplanes'. There's a long table and they grab you by the scruff of the neck then they say: 'Onto the table', like this (gesticulates lying on belly). Then there's a wall, and they throw you hard, and you sail (along the table). Now, you can't protect yourself and hold onto anything. And when you've crashed (into the wall) you can end up being unconscious."

Police victimization of street children, is common in most countries of the world (Venter 1997: 18). Arrested children, or children 'taken into care', are often abused by using fists, hosepipes, leather straps, belts, boots or even electric shocks. The street children in South Africa often describe the police as kind, but when they are asked to draw pictures, it tells another story.

After becoming aware that the police are the major source of violence, for street children, NICRO (with financial support from Amnesty International), decided to involve the Sunnyside street children to relate their experiences with the police through song, art and play. From NICRO's report it becomes clear that the police are indeed not fully informed or sensitive about the street child and his feelings, emotions and circumstances (Venter 1997: 19).

\section{Institutions}

Many street children are still taken to overcrowded public institutions, although events such as murders and revolts within such institutions occur. State institutions are still places that trigger negative associations in the minds of street children. There are scandalous cases, such as the 'clean-up operation' in 1974, when 100 vagrant children on the streets of Sao Paulo were caught and murdered (Novartis Foundation 2000). Swart-Kruger (1994: 232), states that: most street children refuse to be subjected to upliftment programmes within the context of an institution.

It often happens that the children are taken from the streets to an institution, to free them from the hazards of the street, but they are worse off at this 'place of safety'. According to Venter (1997: 25), common reasons are:

- understaffed institutions;

- unqualified, underpaid staff, with a low morale;

- $\quad$ physical abuse;

- $\quad$ poor food;

- manual labor; and

- overcrowding.

The victimization problem does not only involve the staff, but also the inmates. Nine-year-old Edyan (Williams 1996: 42) was arrested for the first time, and taken to an institution. As part of his initiation, all the older boys raped him on his arrival.

The Child Amendment Act of 1995 makes it clear, that a child may be taken to a place of safety if it is considered to 
be in the best interest of the child's safety and welfare. In a discussion, with Douglas from Street-Wise, it was mentioned that it is not correct to take the child off the street, with the aim of cleaning the street.

A major problem for social workers is the fact that, the longer the child remains in the streets, the more difficult it becomes to unite him with his family (Swart-Kruger 1996: 202). A child, taken from the street, should be involved in a programme to prepare him for re-entry into the community and his family life. It is imperative that he should be helped to cope with his emotions. The best place for this to take place is at an institution (Venter 1997: 26).

Current legislation protects street children from obvious violence. It is a concern, however, that children, who usually have no direct adult support, may not experience this protection. Educating street children about the law, and their rights, is essential. In this sense, it is worth mentioning the current work of NICRO.

Since public attention has been drawn to the worldwide problem of street children, international organizations, government agencies, private welfare organizations and associations, have increasingly chosen street children as a focus of their work. This is positive, but it can lead to the 'Calcutta Syndrome', where compassion is temporarily lavished, mainly on smaller children.

Street children are actually wooed by many projects. Therefore, the streets become particularly attractive to children from the slums. Although this does not get these children off the streets, they move rapidly from one project to another, taking advantage of what is on offer (Novartis Foundation 2000).

\section{Vulnerability versus coping Physical development}

The major physical developmental risks, and sources of vulnerability, to which street children may be exposed, relate to shelter, safety, nutrition and untreated illnesses and injuries, glue sniffing and sexual activities. In particular, the lack of shelter and insufficient protective clothing, lead to physical exposure to the cold and damp, vulnerability to pedestrian traffic accidents, exposure to violence, and physical abuse.

The counterbalance to some of these risks is evident in ingenious adaptive strategies regarding income generation, and the acquisition of food and clothing, under the most difficult circumstances. Although this is opportunistic, it is generally successful as a survival strategy.

Children repeatedly claim that they are better off under these conditions than they were at home (Cockburn 1991: 145149).

Although groups of street children have been clearly distinguished from gangs, in their dynamics and social structure (Swart 1988: 32), the role of the group is significant in terms of physical survival. It is concerned with resource and information sharing, and group protection against violence, robbery or police harassment (Swart-Kruger 1994: 107). Also, since street children are afraid to lose their anonymity and to find themselves in the hands of the authorities, the children keep most illnesses and injuries to themselves. Group members are frequently the only source of support and care during such crises (Gebers 1990: 11).

In terms of physical development, it is clear that street children are vulnerable to a range of severe risks. Some of these risks are at least contained through coping strategies and adaptations that street children have evolved, in order to survive. Significantly, on a physical level, these strategies are felt to yield a better life than the one left behind, or the life in a closed childcare institution of one form or another (Richter 1991: 5). It is also clear that the real risks to physical development are long-term.

\section{Emotional development}

Emotionally, the greatest risk to which most street children are exposed is the loss, or lack of, an adequate relationship with an adult caregiver. In terms of the attachment theory (Bowlby 1988: 44), and the development effects on basic emotional security, trust, identification and psychological nurturing, this loss/lack has profound implications. Ironically, street children frequently report that the lack of such a relationship in their pre-street life, was an important factor in their choice, or forced acceptance of street life.

Even where actual loss has not occurred, Richter (1991: 7) estimates that less than ten per cent $(10 \%)$, of street children are actual orphans. Street children typically report that their homes of origin were punitive, rejective and hostile. They also report that their homes lacked adult emotional support (Cockburn 1991: 145). Further, Cockburn (1991: 12) reports exceptionally high levels of physical $(50 \%)$ and sexual $(17 \%)$ abuse, in the families of origin, in a sample of street children. In a different sample, Giles, (1990: 140) reports similarly high levels of assault within families (40\%). He also records that ninety five per cent $(95 \%)$, of the mothers in this sample were unmarried, and most lived in temporarily constituted relationships. Of these mothers, 72 per cent were teenagers when their first child was born. Alcohol abuse was almost universal in these families.

Reliable research evidence, of the negative effects of all this on emotional stability, is limited. However, in at least one study (Richter 1988: 11), higher than normal rates of enuresis, regressive behavior, anxiety and depression were found in a sample of street children, in Johannesburg. Less formally, it has been found in non-governmental organizations' projects in South Africa (endorsed by experience in similar projects in South America), that street children acutely experience unmet affection and dependency needs. At least one repercussion of this is that adequate engagement with secondary goals - such as education - has been found to be problematic, until such primary emotional needs have been met (Swart 1990: 5).

Despite the widespread report of the loss, or lack, of emo- 
tional support from adult caregivers, in their homes of origin, not all street children give up their homes completely. Whether this is adaptive or not, is unclear. In Richter's (1996: 34) sample, for instance, it was found that children who had retained some link with their families, showed more signs of emotional disturbance than those who had broken off completely.

The strongest question of emotional vulnerability, relates to the development of autonomy. Street children consistently report that freedom is both the goal and the highest value of their street existence. Scharf, Powell \& Thomas (1986: 272) portrays this as "freedom from institutions, freedom of movement, freedom from commitments." The emotional cost of achieving freedom is likely to be high, and the value placed on 'freedom' may, in par, be seen as a defensive denial of that cost. But the very exercise of such freedom does have implications for the development of a sense of autonomy and self-reliance that may be positive, in the overall emotional development of the street child. The dependence fostered by street life, appears to promote a sense of togetherness in these children that should not be underestimated in its developmental implications.

Although the role of the street group, in terms of physical survival, is relatively clear, the role it may have in terms of developmentally significant emotional support, is less certain. Despite the popular notion that the group becomes the street child's substitute 'family' (in the sense that it helps to provide in some survival needs and some degree of protection, companionship and support), the analogy is misleading. The relationships within a street group are by nature erratic, temporary, and constituted at a fundamentally different emotional level, than those of adults and children within a family. Nevertheless, the degree of emotional bonding and support, presented in these groups, is frequently evident (Swart 1990: 12). Whilst different to the relationship of adult to child, the support in these groups may act as a significant emotional buffer in the lives of street children.

\section{Social development}

In terms of social identity formation, street children are particularly vulnerable to a range of negative attributions (Swart-Kruger 1994: 172). The most powerful of these is the position of 'social reject'. Street children are socially marginalized and rejected by almost all sections of the community. This takes on obvious forms, such as rejection by families and the children's home community. It also manifests in police harassment, physical and sexual molestation, and inadequate care provided by state welfare structures (Swart-Kruger 1994: 172). Street children are (in its less commonly recognized form), harassed by other more powerful street dwellers. This includes homeless adults, prostitutes and gangs (Gebers 1990: 11). Street children are also commonly characterized and stereotyped as criminals and morally depraved people (Swart 1988: 32). This attribution results in attitudes of rejection from the community and acts of victimization, at both a formal level and informal level, in the social structure. Under these conditions, the development of any positive sense of social identity and self-worth is put at great risk. It is not surprising that selfesteem among street children is commonly reported to be low and self-deprecatory (Cockburn 1991: 12).

Superficially, social development, in terms of peer relationships, appears unproblematic. Physical survival generally takes precedence over other needs and relationships. Thus, the composition of street groups and friendships is consistently reported as fluid, erratic, and subject to the pragmatic demands of individual survival (Giles 1990: 140). Although not absolute, this is likely to affect the establishment of more permanent peer relationships, and the developmental benefits that flow from them.

Set against this, a degree of mutual support, although not based on long-term relationships, is evident in street groups. Sharing, caring and group survival strategies are positive factors in social development (Swart-Kruger 1994: 172). Equally, although there is a cluster of powerful negative attributions directed at street children, evidence indicates that peer morality - a sense of altruism and mutuality - is strong (Swart 1988: 34). Most street children also identify with somewhat idealized, but stable and "conventional working class expectations"' (Scharf, Powell \& Thomas 1986: 280).

Built out of such social experiences, life aspirations, and the sense of having been a 'survivor' under the most difficult circumstances, a basis for an effective adult social identity may be created. The danger of judging such a base from a moral, rather than a psychological position, should be clearly apparent, yet this very confusion is the basis for misunderstanding the street child issue (Swart-Kruger 1994: 172).

\section{References}

ALLISON, W \& JERROM, D 1984: Glue sniffing: a pilot study of the cognitive effects of long term use. The International Journal of the Addictions. vol. 19, p. 453-458.

BARRET, MJ 1995: Street children need our care. Cape Town: Kagiso Publishers.

BUCKNER, JC \& BASSUK, EL 1997: Mental disorders and services utilization among youths from homeless and low-income housed families. Journal of American Academic Child Adolescent Psychiatry. vol. 36, p. 890-900.

"Catholic Action For Street Children". Homepage of CAS http://www.btinternet. comcas/medical.htm [21 Sept 2000].

Catholic Action For Street Children. Homepage of Fieldwork. http://www.btinternet.com/ cas/fieldwk.htm [21 Sept. 2000].

COCKBURN, A 1991: From concern to concrete action: the story of The Homestead. In B. Gannon (Ed), Today's child; tomorrow's adult. Cape Town: National Association of Child Care Workers. 
DONALD, D \& SWART-KRUGER, J 1994: The South African street child: developmental implications. South African Psvchology. 24(4): 169-174.

ENNEW, J 1996: Difficult circumstances: some reflection on street children in Africa. Africa Insight. vol. 26, no 3, p. 203-209.

ESPINOLA B; GLAUSER, B; ORTIZ, R \& ORTIZ DE CARRIZOSA, S 1987: In the streets: working street children in Asuncion. Bogota: UNICEF.

GEBERS, P 1990: Health of street children in Cape Town. The Child Care Worker, 8: 11-14.

GILES, B 1990: Street children: a brief psychological profile. (In: B. Gannon (Ed), Today's child tomorrow's adult. Cape Town: National Association of Child Care Workers. p. 140-144).

NICRO 1997: Art Workshop with Street Children, Sunnyside (Pretoria) on children's rights and perceptions of police - The Report. Unpublished.

RICHTER, LM 1988: Street children: the nature and scope of the problem in Southern Africa. The Child Care Worker. 6:11-14.

RICHTER, LM 1991: Street children in South Africa: street children in rich and poor countries. The Child Care Worker. 9:5-7.

RICHTER, LM 1996: The psychological assessment of South African street children. Africa insight. 29(3): 33-36.

SCHARF W; POWELL, M \& THOMAS, E 1986: Strollers - Street children of Cape Town. (In: S Burman, and P Reynolds, (Eds.), Growing up in a society: the contexts of childhood in South Africa). Johannesburg: Ravan Press.

SIMMS, MD 1998: Medical care of children who are homeless or in foster care. Current options in Pediatrics. 10: 488490.

Sticky Business 2000: Homepage of Street Children and Inhalants. http://www.casa-alianza.org/EN/street-children/ glue/ (21 Sept. 2000).

Street Children in Brazil 2000: Homepage of Novartis Foundation. http://www.foundation.novartis.com/ brazilian_street_children.htm [21 Sept. 2000].

SWART, J 1987: Street children: refugees, dropouts or survivors? The Child Care Worker. 5: 6-8.

SWART, J 1988: Street-Wise: opening the way to selfactualization for street children. Africa Insight. vol. 18: 3241.

SWART, J 1990: Street children: their health and welfare. Journal of Comprehensive Health in South Africa. 1: 5-12.
SWART-KRUGER, J 1994: Children of the South African streets. (In A Dawes and D Donald (Eds.), Childhood and adversity: perspectives from South African research). Cape Town: David Philips.

VENTER, M 1997: Street children a reality. Unpublished.

WILLIAMS, CG 1996: Street children and abuse of power. Africa Insight. 26(3): 33-42. 